\title{
Comparison of dust related respiratory effects in Dutch and Canadian grain handling industries: a pooled analysis
}

\author{
S J M Peelen, D Heederik, H D Dimich-Ward, M Chan-Yeung, S M Kennedy
}

\begin{abstract}
Objectives-Four previously conducted epidemiological studies in more than 1200 grain workers were used to compare exposure-response relations between exposure to grain dust and respiratory health.

Methods-The studies included Dutch workers from an animal feed mill and a transfer grain elevator and Canadian workers from a terminal grain elevator and the docks. Relations between forced expiratory volume in one second $\left(F_{E V}\right)$ and exposure were analysed with multiple regression analysis corrected for smoking, age, and height. Exposure variables examined included cumulative and current dust exposure and the numbers of years a subject was employed in the industry. Sampling efficiencies of the Dutch and Canadian measurement techniques were compared in a pilot study. Results of this study were used to correct slopes of exposure-response relations for differences in dust fractions sampled by Dutch and Canadian personal dust samplers.
\end{abstract}

Results-Negative exposure-response relations were shown for regressions of $F E V_{1}$ on cumulative and current exposure and years employed. Slopes of the exposure-response relations differed by a factor of three to five between industries, apart from results for cumulative exposure. Here the variation in slopes differed by a factor of 100 , from -1 to -0.009 $\mathrm{ml} / \mathrm{mg} \cdot \mathrm{y} / \mathrm{m}^{3}$. The variation in slopes between industries reduced to between twofold to fivefold when the Dutch transfer elevator workers were not considered. There was evidence that the small exposure-response slope found for this group is caused by misclassification of exposure and a strong healthy worker effect. Alternative, but less likely explanations for the variation in slopes were differences in exposure concentrations, composition of grain dust, exposure characteristics, and measurement techniques.

Conclusion-In conclusion, this study showed moderately similar negative exposure-response relations for four different populations from different countries, despite differences in methods of exposure assessment and exposure estimation.
(Occup Environ Med 1996;53:559-566)

Keywords: grain dust; lung function; respiratory health

Growing, transporting, and processing of grain are major industries worldwide. In Canada, about 30000 people work in large terminal grain elevators or small country elevators where grain is stored. ${ }^{1}$ In the longshore industry, where ships are loaded, only about 150 grain handlers are employed in western Canada. In The Netherlands about 10000 25000 workers are exposed to grain dust when handling grain and related products. In the animal feed industry about 6000 people work in production departments, ${ }^{2}$ and several thousands work for elevator companies, where they unload ships. ${ }^{3}$

Exposure to grain dust has the potential to induce several different diseases, ${ }^{4}$ among which respiratory effects have been reported in several studies. ${ }^{5} \mathrm{~A}$ few studies have indicated a relation between current exposure to grain dust and impairment of lung function. ${ }^{6-9}$ Sheridan et al showed a relation between duration of employment and lung function. ${ }^{10}$ Two other studies showed that impairment of lung function is related to the cumulative exposure to grain dust as well as to the duration of exposure. ${ }^{11} 12$ Huy et al also showed a dose-response relation for symptoms and exposure to grain dust. $^{12}$ In contrast, Smid et al showed a decreasing prevalence of symptoms with increasing years of employment, indicative of a healthy worker effect. " A detailed comparison of the magnitude of the effect on the respiratory system found in different studies is seldom possible because methods of analysing exposure-response relations differ across studies. To facilitate a comparison, we combined data from four previously conducted studies of workers exposed to grain dust, carried out by research teams in Canada and The Netherlands. These studies all include data on respiratory symptoms, lung function, and exposure to grain dust. Exposure-response relations between forced expiratory volume in one second $\left(\mathrm{FEV}_{1}\right)$ and dust exposure were investigated for the different populations as well as for the pooled dataset, either to find consistencies in the relations which will strengthen the arguments in support of causality, or to find differences in exposure-response relations that may point to important aetiological mechanisms. 


\section{Materials and methods}

POPULATIONS

Study populations include white men, participants from one Dutch animal feed mill study, one Dutch grain transfer elevator study, one Canadian grain terminal elevator study, and one Canadian dock workers study. Maintenance personnel from all groups were excluded as they may have been exposed to other respiratory hazards, such as welding fumes.

The Dutch animal feed industry study included 393 male workers; 315 workers from two animal feed elevators and 12 production factories, ${ }^{11}$ and 78 additional workers from these same factories tested four years later (participation rate $95 \%$ ). ${ }^{13}$ The Dutch transfer grain elevator study, performed in the port of Rotterdam, included 438 grain workers in the study population (participation rate $80 \%$ ). ${ }^{3}$ In the Canadian terminal grain elevator study a total of 339 male grain workers, employed at five terminal elevators in the port of Vancouver, participated in the 1988 respiratory health survey (participation rate $85 \%$ ). ${ }^{12}$ The long shore industry study consisted of 67 dock workers in the port of Vancouver who load grain on to ships (participation rate $83 \%){ }^{14}$

In these industries the processes by which the grain is handled vary greatly. The highly mechanised production process in the Dutch animal feed mill involves unloading, cleaning, and storing raw materials after their arrival in the mill. In a batch process, the raw materials are ground and mixed with fats, molasses, and additives such as vitamins and minerals and subsequently pressed into pellets and stored in silos. ${ }^{11}$ In the Dutch transfer elevators the process involves mainly unloading from ships and storing the grain or transferring to lorries, railway waggons, and small boats. Many of the unloaders work on the ship or inside the vessels where they clean the ship with shovels (trimming).

In Canadian terminal grain elevators, the main tasks are to receive grain from country elevators, transported by railway waggons; to sort, grade, inspect, clean, dry, and store grain in silos; and then to weigh and prepare shipments for export according to specified orders. These mechanised tasks resemble the work performed in the Dutch animal feed industry more than the work performed in the Dutch grain elevator industry. Loading of ships is performed by dock workers. The main functions of these dock workers are to direct the funnelling of grain from elevator conveyors to the hold of the awaiting ships, to even the load, and to clean up the surrounding deck after loading the hold. These workers do not work exclusively on grain loading but may have spent many years of their work on the docks loading other cargoes. Thus, years employed in the industry for this group refers only to years employed in the grain cargo sector.

EXPOSURE

Dust levels measured in all the grain industries are based on gravimetric personal dust measurements, collected over six to eight hours. In the analyses, eight hour time weighted average exposure concentrations were used. In the Dutch animal feed industry and transfer grain elevators, personal inhalable dust samples were taken from the production workers. ${ }^{11} 13$ Inhalable dust was measured with a portable pump at a flow rate of $2.0 \mathrm{l} / \mathrm{minute}$, and a PAS-6 air sampling head with a $6 \mathrm{~mm}$ diameter inlet opening, ${ }^{15}$ on a $2.4 \mathrm{~cm}$ diameter glass fibre filter (Whatman GF/A). The dust sampled is characterised by a theoretical $50 \%$ cut off diameter of $30 \mu \mathrm{m}$; in practice the fraction sampled resembles the inhalable dust fraction that passes the mouth and nostrils when inhaled. ${ }^{16}$ Details of sampling methods for the Dutch studies are given elsewhere. ${ }^{1113}$

In the Canadian studies air sampling was carried out by government inspectors (Labour Canada) and university technicians to measure total personal dust in grain elevators (about every three years from 1974 to 1989) and on the docks while grain was being loaded (current exposure only). Dupont P4 LC pumps (Ametek, Largo, FL) were used to draw air at $1.7 \mathrm{l}$ /minute on to preweighed polyvinyl chloride filters. A two piece plastic close faced cassette $^{17}$ was used to hold the $37 \mathrm{~mm}$ diameter filter with $0 \cdot 8 \mu \mathrm{m}$ pore size. Further details of the sampling strategy are described in Huy et $a l .{ }^{12}$

Also, to assist in the interpretation of the exposure-response relations for this analysis, a pilot study was conducted to compare sampling efficiency of the Dutch and Canadian filter cassettes. Twenty paired area samples were taken in one Canadian terminal elevator, with both sampling devices. The samples were collected over four consecutive days in five different work areas, with a sampling duration of five to eight hours.

As dust levels in the Canadian grain elevators have changed greatly over the past 15 years, current and past exposures were used to calculate cumulative exposure to grain dust for this population. The other studies either had no available previous measurements of dust exposure, or showed no change in the processes for handling grain. For these studies cumulative exposure was calculated from current exposures only. Arithmetic mean exposures for occupational categories were used to estimate cumulative exposure for workers who did not participate in the exposure assessment study. The product of the arithmetic mean dust exposure for the occupational category and the number of years employed in that job category was computed for every job that was reported by the worker. Cumulative exposure, expressed in mg.y/m $/ \mathrm{m}^{3}$, was computed for each worker by adding the results for all jobs held. The calculation of cumulative exposure for the Canadian transfer industry population was slightly different. There each job title was assigned to one of the four exposure categories for each of three time periods. Dust concentrations used for calculations were the arithmetic mean values for all jobs in each of the four exposure categories. ${ }^{12}$ 
QUESTIONNAIRE

In the Dutch studies a self administered Dutch version of the British Medical Research Council questionnaire was used to collect information on respiratory symptoms. ${ }^{18}$ The questions included chronic cough and chronic phlegm (daily for at least three months during the past two years), shortness of breath, ever wheezing, and frequent wheezing (for at least one week during the past two years). In the Canadian studies a similar respiratory health questionnaire (American Thoracic Society recommended questionnaire for respiratory epidemiology ${ }^{19}$ ) was given by trained interviewers. ${ }^{20}$ For all analyses, the responses of the Canadian questionnaire were standardised to the Dutch definitions.

\section{LUNG FUNCTION}

Lung function measurements in the Dutch animal feed industry were performed with Vicatest-V dry "rolling seal" spirometers (Mijnhardt, Bunnik, The Netherlands), which were calibrated twice a day with a 31 syringe. Measurements and procedures including body temperature, pressure, and saturation (BTPS) adjustments and procedures of data selection were in accordance with the recommendations of the European Committee on Coal and Steel. ${ }^{21}$ In the Dutch transfer elevator industry, lung function tests were performed with a Vicatest 4 (Mijnhart, Bunnik, The Netherlands). Here the $\mathrm{FEV}_{5}$ was measured instead of the forced vital capacity (FVC). Therefore, the vital capacity was underestimated for some subjects. However, $\mathrm{FEV}_{1}$ measurement is comparable with the results of the Vicatest- $\mathrm{V}$ and this variable could be used for further analysis. A more detailed description of the lung function measurements is given by Smid et al. ${ }^{11}$ In the Canadian studies, spirometry was carried out with a $13 \cdot 5-\mathrm{L}$ Collins water sealed spirometer (Warren E Collins, Braintree, MA) calibrated daily, with a 31 syringe. Function testing was performed according to the American Thoracic Society criteria for spirometric techniques for epidemiological studies, $^{22}$ including BTPS adjustments. A more detailed description is given in Huy et al. ${ }^{12}$ In all studies, subjects were seated, and were also wearing nose clips in the Canadian studies. A minimum of three acceptable forced expiratory manoeuvres were obtained. The best value for $\mathrm{FEV}_{1}$ was used for analysis.

\section{STATISTICAL ANALYSES}

All statistical analyses were performed on a personal computer with SAS-PC statistical analysis software (SAS Institute, Cary, NC). For each group a linear regression model was applied to relate $\mathrm{FEV}_{1}$ to measures of exposure with adjustment for age, height, and packyears of cigarette smoking. The $\mathrm{FEV}_{1}$ was analysed separately for each of the following exposure measures; cumulative exposure to grain dust (mg.y/m $\left.\mathrm{m}^{3}\right)$, number of years worked in the industry, current exposure to grain dust $\left(\mathrm{mg} / \mathrm{m}^{3}\right)$.

To facilitate the evaluation of the potential differences in exposure-response relations for cumulative exposure between industries, all data of the studied industries $(n=1237)$ were combined in one large dataset, arbitrarily taking the Dutch animal feed industry as the control group. To compare the different industries, dummy variables for group and interaction terms were entered in the regression model. Exclusion of interaction terms was based on non-significant $(P>0.01)$ and small regression coefficients.

\section{Results \\ CHARACTERISTICS AND SYMPTOMS OF THE POPULATION}

Table 1 shows mean values for age, height, smoking habits, and exposures to grain dust for the studied populations. The groups differed for all characteristics except height. Mean age was within a close range, with the exception of the Canadian dock workers who were significantly older than the other groups. Smoking histories differed across groups. Smoking was less common among both groups of Canadian workers. If only smokers were considered, the Canadian dock workers smoked the most (14.7 pack-years), and the Dutch animal feed industry workers the least $(10.7$ pack-years). The average number of years employed in the industries differed significantly from 9.8 years (Canadian dock workers) to 14.8 years (Dutch transfer elevator workers). Table 1 also shows the mean percentage of predicted values for

Table 1 Characteristics of study populations

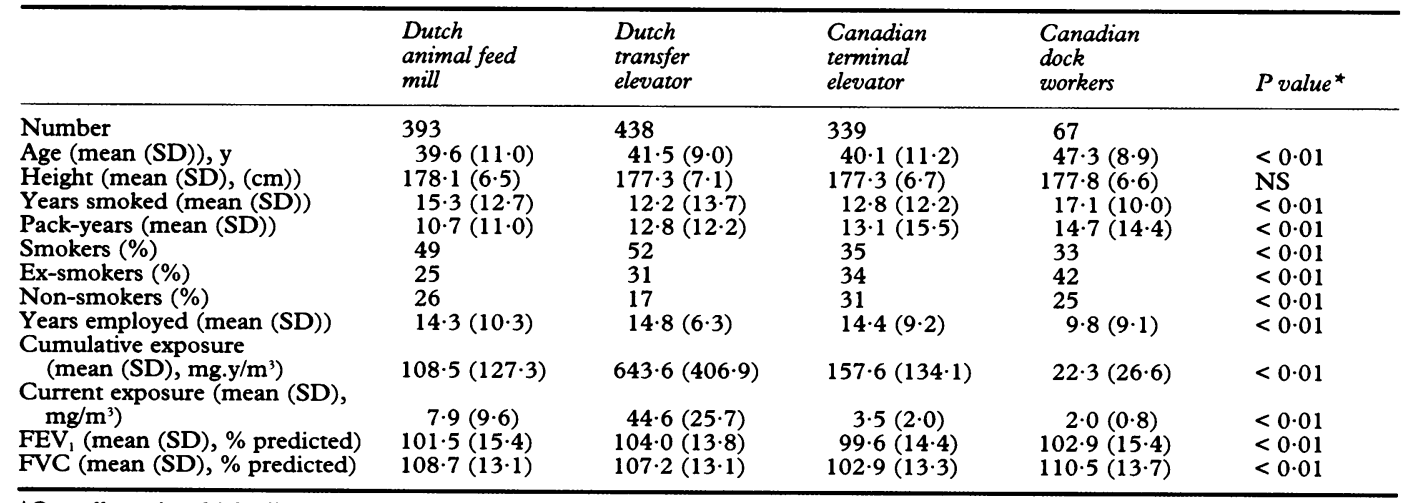

*Overall test in which all groups differ, by ANOVA and $\chi^{2}$ statistics. 
Table 2 Prevalence rates for respiratory symptoms by industry

\begin{tabular}{llllll}
\hline & $\begin{array}{l}\text { Dutch } \\
\text { animal feed } \\
\text { mill } \\
\%\end{array}$ & $\begin{array}{l}\text { Dutch } \\
\text { transfer } \\
\text { elevator } \\
\%\end{array}$ & $\begin{array}{l}\text { Canadian } \\
\text { terminal } \\
\text { elevator } \\
\%\end{array}$ & $\begin{array}{l}\text { Canadian } \\
\text { dock } \\
\text { workers } \\
\%\end{array}$ & $P^{\text {Symptom }}$ \\
\hline Chronic cough & 8 & 11 & 14 & 15 & $<0.01$ \\
Chronic phlegm & 4 & 10 & 19 & 24 & $<0.01$ \\
Breathlessness & 5 & 10 & 17 & 6 & $<0.01$ \\
Ever wheeze & 15 & 24 & 18 & 30 & $<01$ \\
Frequent wheeze & 5 & 12 & 6 & 9 & $<01$ \\
\hline
\end{tabular}

*Overall test in which all groups differ, by $\chi^{2}$ statistics.

Figure 1 Comparison of the sampling efficiency of the Dutch and Canadian sampling devices.

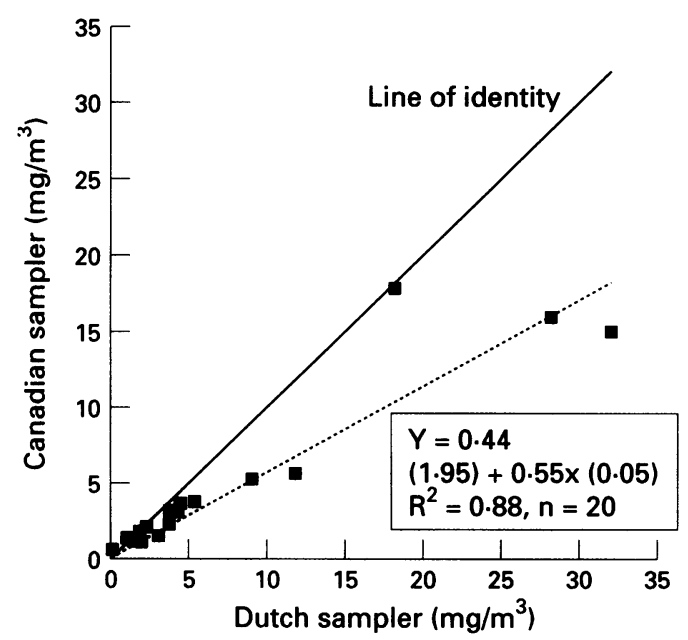

$\mathrm{FEV}_{1}$ and FVC with recently published reference values for white men. ${ }^{21}$ The average lung function values for workers in the Dutch and Canadian ship loading industries did not differ from the control values, but the Canadian terminal elevator workers had lower average values. With the reference values of Crapo et al, ${ }^{23}$ which were used in the original analyses of the Canadian data, the ranges of mean percentages of predicted values were about the same, but all values were lower on average (not shown in the table).

Table 2 shows prevalence rates for respiratory symptoms. For all symptoms shown, significant differences were found between groups. Rates for the animal feed industry tended to be low for all symptoms, whereas, rates in the Canadian dock workers were highest. In all groups, the most prevalent symptom reported was ever wheezing.

\section{EXPOSURE CHARACTERISTICS}

Dust exposures seem to vary greatly among industries. Workers in the Dutch transfer elevator study experienced the highest mean current $\left(44.6 \mathrm{mg} / \mathrm{m}^{3}\right)$ and cumulative exposures (643.6 mg.y $\left./ \mathrm{m}^{3}\right)$. The Canadian dock workers had the lowest mean exposures for both current and cumulative exposure; for current exposure there was a 22 -fold difference $(2 \cdot 0$ $\mathrm{mg} / \mathrm{m}^{3}$ ) and for cumulative exposure a 29-fold difference $\left(22.3 \mathrm{mg} . \mathrm{y} / \mathrm{m}^{3}\right)$ compared with the Dutch transfer elevator study. The exposure concentrations of the other industries varied between these extremes (table 1).

Figure 1 shows the results of the comparison of the parallel dust sampling, from Dutch and Canadian sampling devices, with the line of identity (slope $=1$, intercept $=0$ ) superimposed on the graph. Linear regression analysis, comparing the grain dust concentrations from the parallel samples resulted in a regression coefficient of $0.55\left(R^{2}=0.88\right)$, indicating that the Dutch device samples more dust than the Canadian sampling device. As the Dutch device samples dust which closely resembles standard inhalable dust, ${ }^{16}$ the Canadian sampled concentrations could be roughly corrected by multiplying by a factor of two. As the parallel dust sampling was only a pilot study with a few samples, results were not adjusted for the difference between samples except for the comparison in the pooled analyses.

Different job titles for each industry were combined into job categories. Table 3 shows some of the different job categories, stratified into high and low mean current dust exposure, with low exposure groups having current concentrations under the currently regulated

Table 3 fob category stratified by current mean exposure concentration

\begin{tabular}{|c|c|c|c|c|}
\hline \multirow[b]{2}{*}{ Industry } & \multicolumn{2}{|l|}{ High exposure } & \multicolumn{2}{|l|}{ Low exposure } \\
\hline & fob title & $\begin{array}{l}\text { Dust concentration } \\
\text { mean }\left(\mathrm{mg} / \mathrm{m}^{3}\right)\end{array}$ & Fob title & $\begin{array}{l}\text { Dust concentration } \\
\text { mean }\left(\mathrm{mg} / \mathrm{m}^{3}\right)\end{array}$ \\
\hline Dutch animal feed mill & $\begin{array}{l}\text { Unloaders } \\
\text { Clean-up } \\
\text { Machine operators } \\
\text { Labourers }\end{array}$ & $\begin{array}{l}30 \\
12\end{array}$ & $\begin{array}{l}\text { Crane drivers } \\
\text { Process operators } \\
\text { Managers } \\
\text { Transport workers } \\
\text { Sackers }\end{array}$ & $<5$ \\
\hline Dutch transfer elevator & $\begin{array}{l}\text { Unloaders } \\
\text { General labour } \\
\text { Machine operators } \\
\text { Elevator workers } \\
\text { Mechanics }\end{array}$ & $\begin{array}{r}53 \\
117 \\
58 \\
94\end{array}$ & $\begin{array}{l}\text { Supervisors } \\
\text { Foremen } \\
\text { Office workers } \\
\text { Shippers } \\
\text { Drivers } \\
\text { Boot workers }\end{array}$ & $<10$ \\
\hline Canadian terminal elevator & - & & $\begin{array}{l}\text { Unloaders } \\
\text { Labourers } \\
\text { Machine operators } \\
\text { Foremen office }\end{array}$ & $\begin{array}{l}5 \cdot 5 \\
1.5\end{array}$ \\
\hline Canadian dock workers & - & & $\begin{array}{l}\text { Loaders } \\
\text { Machine operators } \\
\text { Foremen }\end{array}$ & $<3$ \\
\hline
\end{tabular}


Table 4 Relation ( $\beta$ ) between years employed in the industry, cumulative dust, and current dust exposure and $F E V_{1}$, after adjustment for age, height, and pack-years, separately calculated for each group

\begin{tabular}{|c|c|c|c|c|}
\hline & $\begin{array}{l}\text { Dutch } \\
\text { animal feed } \\
\text { mill }\end{array}$ & $\begin{array}{l}\text { Dutch } \\
\text { transfer } \\
\text { elevator }\end{array}$ & $\begin{array}{l}\text { Canadian } \\
\text { terminal } \\
\text { elevator }\end{array}$ & $\begin{array}{l}\text { Canadian } \\
\text { dock } \\
\text { workers }\end{array}$ \\
\hline $\begin{array}{l}\text { Years employed in industry: } \\
\mathrm{R}^{2} \\
\text { FEV }(\mathrm{ml}): \\
\text { Intercept } \\
\text { Age }(\mathrm{y}) \\
\text { Height }(\mathrm{cm}) \\
\text { Pack-years } \\
\text { Years employed }\end{array}$ & $\begin{array}{l}0 \cdot 57 \\
-4525^{\star \star} \\
-30^{\star \star} \\
56^{\star \star} \\
-8^{\star} \\
-8\end{array}$ & $\begin{array}{l}-2375^{\star \star} \\
-34^{\star \star} \\
45^{\star \star} \\
-7^{\star \star} \\
-3\end{array}$ & $\begin{array}{l}-2175^{\star \star} \\
-33^{\star \star} \\
43^{\star \star} \\
-8^{\star \star} \\
-3\end{array}$ & $\begin{array}{l}-2153 \\
-26^{\star \star} \\
42^{\star \star} \\
-15^{\star \star} \\
-6\end{array}$ \\
\hline $\begin{array}{l}\text { Cumulative exposure: } \\
\mathbf{R}^{2} \\
\text { FEV }_{1}(\mathrm{ml}): \\
\text { Intercept } \\
\text { Age }(\mathrm{y}) \\
\text { Height }(\mathrm{cm}) \\
\text { Pack-years } \\
\text { Cumulative exposure } \\
\left(\mathrm{mg} \cdot \mathrm{y} / \mathrm{m}^{3}\right)\end{array}$ & $\begin{array}{l}-4396^{\star \star} \\
-32^{\star \star} \\
56^{\star \star} \\
-7^{\star} \\
-0.9^{\star \star}\end{array}$ & $\begin{array}{l}-2350^{\star \star} \\
-36^{\star \star} \\
45^{\star \star} \\
-7^{\star \star} \\
-0.009\end{array}$ & $\begin{array}{l}0.53 \\
-2252^{\star \star} \\
-30^{\star \star} \\
43^{\star \star} \\
-9^{\star \star} \\
-0.6^{\star}\end{array}$ & $\begin{array}{l}0.45 \\
-1976 \\
-28^{\star \star} \\
42^{\star \star} \\
-14^{\star \star} \\
-1 \cdot 0\end{array}$ \\
\hline $\begin{array}{l}\text { Current exposure: } \\
\mathrm{R}^{2} \\
\text { FEV }_{1}(\mathrm{ml}): \\
\text { Intercept } \\
\text { Age }(\mathrm{y}) \\
\text { Height }(\mathrm{cm}) \\
\text { Pack-years } \\
\text { Current exposure } \\
\left(\mathrm{mg} / \mathrm{m}^{3}\right)\end{array}$ & $\begin{array}{l}-4441^{\star \star} \\
-37^{\star \star} \\
57^{\star \star} \\
-8^{\star} \\
-9^{\star \star}\end{array}$ & $\begin{array}{l}-2189^{\star \star} \\
-36^{\star \star} \\
45^{\star \star} \\
-7^{\star \star} \\
-2^{\star}\end{array}$ & $\begin{array}{l}-2085^{\star \star} \\
-34^{\star \star} \\
43^{\star \star} \\
-9^{\star \star} \\
-8\end{array}$ & $\begin{array}{l}- \\
-\end{array}$ \\
\hline
\end{tabular}

${ }^{\star} \mathrm{P}<0.051 ;{ }^{\star \star} \mathrm{P}<0.01$.

value of $10 \mathrm{mg} / \mathrm{m}^{3}$ and high exposure groups having concentrations above this value. Personal mean dust exposures ranged in the Dutch animal feed industry from $<1.8$ to 37 $\mathrm{mg} / \mathrm{m}^{3}$ and in the Dutch grain industry from $<10$ to $116 \mathrm{mg} / \mathrm{m}^{3}$. The range of exposure in the Canadian industries was less, from 1.5 to $5.5 \mathrm{mg} / \mathrm{m}^{3}$ and $<3.0 \mathrm{mg} / \mathrm{m}^{3}$ for respectively the Canadian terminal elevator group and dock workers.

\section{EXPOSURE RESPONSE RELATIONS}

Table 4 shows the regression coefficients from separate group analyses of $\mathrm{FEV}_{1}$ on the exposure variables years employed in the industry, cumulative exposure, and current exposure. Each regression model included one of these three exposure variables, adjusted for age, height, and pack-years of smoking. The relation between years employed in the industry and $\mathrm{FEV}_{1}$ was not significant for any group, although it was highest for the Dutch animal feed workers. All slopes differed within a range of a factor of two to three. Replacing the variable years worked in production areas for years worked in the industry the regression model for the animal feed industry yielded a signifi-

Table 5 Relation between cumulative exposure and FEV after adjustment for dummy variables for group, interaction term cumulative exposure of group 2 (Dutch transfer elevator group) and the confounders age, height and pack-years of smoking, in a group of 1237 Canadian and Dutch grain workers $\left(R^{2}=0.55\right)$

\begin{tabular}{|c|c|c|c|}
\hline Variables* & $\begin{array}{l}\text { Regression } \\
\text { coefficient }\end{array}$ & Standard error & $P$ values \\
\hline 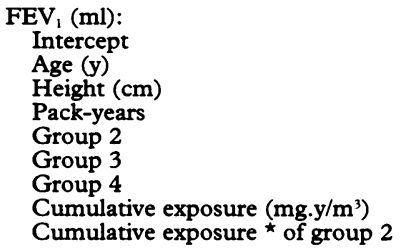 & $\begin{array}{c}-2999 \\
-32 \\
48 \\
9 \\
51 \\
-24 \\
51 \\
-0 \cdot 7 \\
0.7\end{array}$ & $\begin{array}{l}446 \\
2 \\
2 \\
1 \\
58 \\
41 \\
78 \\
0 \cdot 2 \\
0 \cdot 2\end{array}$ & $\begin{aligned}< & 0.01 \\
< & 0.01 \\
< & 0.01 \\
< & 0.01 \\
& 0.38 \\
& 0.55 \\
& 0.51 \\
< & 0.01 \\
< & 0.01\end{aligned}$ \\
\hline
\end{tabular}

*Group 2 = dummy variable for Dutch transfer elevator group;

Group 3 = dummy variable for Canadian terminal elevator group;

Group 4 = dummy variable for Canadian dock worker group. cant coefficient of $-14 \mathrm{ml} / \mathrm{y}(P<0.01$, not shown in the table).

Although not always significant, the magnitude of the exposure-response relations for cumulative exposure and $\mathrm{FEV}_{1}$ were about the same for the studied industries, ranging by a factor of two, except for the Dutch transfer elevator industry. The slope for the Dutch transfer workers was about 100 times less, although the exposures to grain dust in the Dutch transfer elevator were higher.

The relations between $\mathrm{FEV}_{1}$ and current exposure to grain dust in the animal feed industry and the Canadian terminal elevators were similar and were about four times larger than in the Dutch grain elevator industry. The effect of current exposure on $\mathrm{FEV}_{1}$ was significant for the studied industries except the Canadian terminal grain elevators.

With the regression coefficients of lung function on current exposure from the models in table 4, the following estimated $\mathrm{FEV}_{1}$ losses for the overall mean dust concentration per industry (table 1) were calculated; $71 \mathrm{ml}$ for the animal feed workers, $89 \mathrm{ml}$ for the Dutch transfer elevator workers, and $28 \mathrm{ml}$ for the Canadian terminal elevator workers.

Unadjusted and adjusted Canadian exposure data on the 1237 tested workers were combined to calculate the potential significant differences in exposure-response relations for cumulative exposure of the different industries. In this pooled analyses the exposureresponse relation of the Dutch animal feed industry was arbitrarily taken as the control group. The final model related $\mathrm{FEV}_{1}$ to cumulative exposure, and included dummy variables for each group, an interaction term for cumulative exposure with the Dutch transfer elevator), and the confounders age, height, and pack-years of cigarette smoking (table 5). Exclusion of interaction terms "group with pack-years smoking", "group with age", "group with height", and "group with cumulative exposure" from the models was based on non-significant $(P>0.01)$ and small regression coefficients. The dummy variables for the group were included in the model to show that there was no significant group effect in this analysis.

The slope of $\mathrm{FEV}_{1}$ on cumulative exposure for the Dutch animal feed population $(\beta=$ $-0.7 \mathrm{ml} / \mathrm{mg} . \mathrm{y} / \mathrm{m}^{3}$ ) showed no significant difference from the slopes for the Canadian populations (table 5). Only the slope of the Dutch transfer industry differed significantly from the control group, $\Delta \beta \simeq 0 \mathrm{ml} / \mathrm{mg} . \mathrm{y} / \mathrm{m}^{3},(P<0.01$, difference in slope in comparison with the control group). The exposure-response relations for cumulative exposure for the studied populations (table 5) have been shown graphically in figure 2 , with the 5 and 95 percentiles as minimum and maximum values of exposure. The range in exposure measured in the Canadian longshore industry was small, 0-89 mg.y $/ \mathrm{m}^{3}$, and very wide in the Dutch grain elevator industry, $94-1300 \mathrm{mg} . \mathrm{y} / \mathrm{m}^{3}$. The range in exposure for the Dutch animal feed mill (0-370 mg.y/m $\mathrm{m}^{3}$ ) and Canadian grain elevator industry (13-439 mg.y/m $\left./ \mathrm{m}^{3}\right)$ were com- 


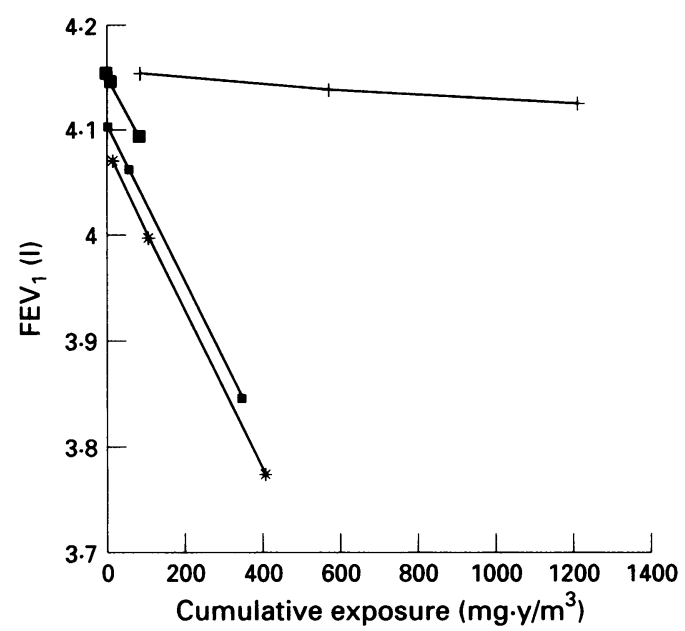

Figure 2 Exposure-response relations for cumulative exposure and $F E V_{1}$. Exposure-response relations presented are given for 5\%, 50\% (median), and $95 \%$ of the cumulative exposure distribution for each population, for an average non-smoking grain worker of age $=40$ years, height $=175 \mathrm{~cm} . \quad=$ Dutch animal feed industry;

$+=$ Dutch transfer elevator industry; ${ }^{*}=$ Canadian terminal elevator industry; = Canadian dock workers.

parable. Application of a correction for differences in sampling equipment on the Canadian data led to a model which also included the significant interaction term for cumulative exposure with the Canadian terminal elevator group, showing that the exposure-response relation for the control group $(\beta=-0.8$ $\mathrm{ml} / \mathrm{mg} \cdot \mathrm{y} / \mathrm{m}^{3}$ ) compared with the Canadian terminal elevator group was also significantly different $\left(\Delta \beta=-0.2 \mathrm{ml} / \mathrm{mg} . \mathrm{y} / \mathrm{m}^{3}, \mathrm{P}<0.01\right)$. The adjustment for differences between samplers resulted in wider cumulative exposure ranges for the Canadian industries. The range in exposure for the Canadian terminal elevator group and the Canadian longshore industry group became $26-818 \mathrm{mg} . \mathrm{y} / \mathrm{m}^{3}$ and $1-178$ $\mathrm{mg} . \mathrm{y} / \mathrm{m}^{3}$, respectively.

\section{Discussion}

Attempting to compare results from different studies is useful, as finding consistencies in exposure-response relations across studies strengthens arguments in support of causality. On the other hand, finding differences in exposure-response relations may point to important aetiological mechanisms. From this study it can be concluded that, despite differences in exposure concentrations, exposure characteristics, response measures, and measurement techniques there is a negative exposure-response relation between grain dust and lung function for all the studied industries. However, the magnitude of the effects differed for the various grain industries, although the range of exposure-response relations was small.

Several other epidemiological studies that were conducted in grain workers indicated respiratory effects of exposure to grain dust. Some studies showed relations between current exposure and respiratory disorders. ${ }^{67924}$ In two studies a relation with duration of employment was found. ${ }^{810}$ Two studies of Smid et $a,^{11}$ and Huy et al, ${ }^{12}$ also used in this analysis, showed that impairment of lung function is related to cumulative grain dust concentrations as well as to duration of exposure. These studies all showed negative exposure-response relations for exposure to grain dust and lung function. However, a detailed comparison of the size of the respiratory effects could not be performed on the basis of the results published because different statistical techniques were used and cumulative exposure was calculated in a different way in one study. ${ }^{12}$ In this analysis similar statistical approaches were applied, and calculation of the cumulative exposure was harmonised.

Comparison of the exposure-response relations between $\mathrm{FEV}_{1}$ and cumulative and current exposure and years employed in the industry showed moderate agreement. Slopes of the exposure-response relation differed by a factor of three to five between industries for the different exposure variables, apart from the results for cumulative exposure. Here the variation in slopes ranged by a factor of 100 , from -1 to $-0.009 \mathrm{ml} / \mathrm{mg} \cdot \mathrm{y} / \mathrm{m}^{3}$, caused by the very small coefficient for the Dutch transfer elevator industry. The variation in slopes between the industries reduced to a factor of two to five when the Dutch transfer elevator workers were not considered. With the pooled regression, analyses in which all data from the four populations were combined showed that only the small coefficient for the Dutch transfer elevator industry differed significantly from that of the Dutch animal feed industry. This points to moderately similar negative exposure-response relations in this study.

The most likely explanations for the small regression coefficient for the Dutch transfer elevator group are misclassification of exposure and the healthy worker effect. Misclassification of exposure in the Dutch grain elevator group could have caused attenuation of the slope of the exposure-response relation. ${ }^{3}$ Relatively strong misclassification could have occurred because the unloaders in this industry have a greater range in exposure but they were grouped in fewer exposure categories than other populations. The means of exposure for the exposure categories showed wide confidence intervals which point to an inhomogeneous exposure group. Because of job rotation a more detailed grouping was impossible. Also, the lowest exposure concentrations of the Dutch transfer elevator group are still high in comparison to other populations. Further, the absence of unexposed workers in this population might have influenced the results considerably as well. Although not as strong as in the Dutch transfer elevator group, misclassification of exposure might have affected other exposure-response relations as well. In the Canadian studies fewer exposure measurements were available which might cause underestimation of the exposure-response relation because of random error in exposure.

A second explanation for differences in exposure-response relations found might be 
the healthy worker effect. Due to the very high exposures in the Dutch grain elevators a relatively strong selection process may have taken place before employment and during early employment. Other studies have shown that grain industry workers who leave the industry are those who have more respiratory symptoms, ${ }^{1125-27}$ indicating that as in the other groups studied the association between exposure to grain dust and impairment of lung function might have been underestimated. However, the very high exposures for the Dutch transfer elevator group with the highest $\mathrm{FEV}_{1} \%$ predicted and the smallest exposureresponse slope suggests that the healthy worker effect may have been stronger among the Dutch transfer workers than the other groups and thus may have biased those results more strongly towards the null.

Other possible explanations which are unlikely to explain the very small coefficient of the Dutch transfer group but can explain some of the variation in regression coefficients between the groups are differences in composition of grain dust, exposure characteristics, and instruments to measure lung function. Firstly, variation in regression coefficients of the studied industries may be associated with the complex nature of grain dust. Differences in composition and in biological activities of grain dust may exist in the various industries as the Canadian terminal grain elevator receives the grain from inland country elevators, and the Dutch elevators get the grain shipped from different countries. Kennedy et $a l^{28}$ and Smid $e t a l^{11}$ concluded from their studies among cotton production workers and animal feed workers that an exposure-response relation exists between endotoxin concentration and $\mathrm{FEV}_{1}$, and that endotoxin concentrations were better predictors for impairment of lung function than dust concentrations. It is possible that the dose-response relation of dust exposure and lung function for these studied grain industries may be influenced by other factors like endotoxin or fungi, which probably differ in each industry.

Secondly, the exposure characteristics are different in the industries studied as some industries are highly mechanised and others rely on a considerable amount of heavy physical labour. The highly mechanised jobs in the Canadian elevator industry and Dutch animal feed industry show an exposure to grain dust which is continuous while at work. The more physical jobs in the Canadian dock industry and Dutch transfer elevator industry show an exposure to grain dust which is intermittent during the working day. Depending on the amount of production Canadian dock workers work a variable number of days at loading grain cargo. The various job categories for each industry also indicate different exposure characteristics for each industry.

Thirdly, differences in measurement of lung function, differences in temperature, pressure, and saturation corrections, and differences in calibrations between the Dutch and Canadian industries may lead to differences in mean values of $\mathrm{FEV}_{1}$. However, a systematic difference between the spirometers (assuming that the errors of the spirometers are linear and within a narrow range as required by the regulatory bodies) would only lead to a change in intercept in the regression analysis, but not to an effect on slopes of exposure-response relations. The change in intercept in the regression would be accompanied by an increase in the standard errors as well. Results of table 5 are not indicative of such a systematic effect on techniques of measurement of lung function.

A pilot study conducted to assist in the interpretation of the exposure-response relations showed that there are differences in measured exposures for the two countries attributable to different measurement techniques. About a twofold difference in exposures was measured between the two cassettes with the Dutch sampling device measuring higher values than the Canadian sampling device. A recently conducted well controlled wind tunnel study to test commonly used instruments to sample workplace aerosols did not show as big a difference between the Canadian and Dutch samplers as found in this field experiment. ${ }^{29}$ As our comparison was performed with a small sample size the results should be interpreted with care.

Comparison of the response measures among the industries showed higher prevalences of symptoms in the Canadian industries than in the Dutch industries. Also in other studies of the grain processing industry conducted in the United States ${ }^{610}$ and a study of animal feed workers in former Yugoslavia, ${ }^{30}$ higher rates of symptoms were found. The lower symptom prevalences in the Dutch industries might indicate that the self administered questionnaire may have low sensitivity compared with oral interviews. Other factors like variations in constituents of grain dust from different sources, job satisfaction, age, smoking habits, cultural differences, or possible selection effects, as mentioned before, may be responsible for the different ways of reporting symptoms.

Comparisons of the exposure concentrations with the response measures for the different industries showed for the Canadian populations low mean current and mean cumulative exposures, with high prevalences of symptoms. The dock worker population was exposed to high peak exposures which varied over the day, and was also not exposed to grain dust on a daily basis. This may account for their increased sensitivity or symptoms.

In conclusion, these studies of exposure to grain dust from different sources, handled in different industries, all show negative exposure-related respiratory effects and confirm earlier published evidence. With the same statistical techniques, detailed comparison of the size of the exposure-response relation on the respiratory effects showed that despite exposure misclassifications, the healthy worker effect, differences in exposure concentrations, exposure characteristics, and sampling devices used to measure the exposure there was a 
moderate agreement in exposure-response relations between the studied industries. To perform even more detailed comparisons between results from different industries and countries, not only should similar statistical techniques be used, but also similar internationally accepted sampling protocols and measurement techniques should be adopted for new studies in the future.

We thank Remko Houba for data retrieval. Wendel Post is acknowledged for conducting the additional dust sampling in the Dutch animal feed industry and Jeroen Douwes for the performance of the parallel dust sampling.

1 NIOSH Technical Report. Study of the prevalence of chronic nonspecific lung disease and related health problems in the grain handling industry. US Department of Health and Human Services, October 1986.

2 Smid T, Heederik D, Mensink G, Houba R, Boleij JSM Exposure to dust, endotoxin and fungi in the animal feed industry. Am Ind Hyg Assoc 7 1992;53:362-8.

3 Heederik D, Houba R, Preller L. Longfunctieonderzoek bij een aan organisch stof blootgestelde populatie bij een overslag bedrijf. Vakgroep Gezondheidsleer en Luchthygiene en -verontreiniging,

4 Cotton DJ, Dosman JA Grain dust and health. I Host factors. Ann Intern Med 1978;88:840-1.

5 Chan-Yeung M, Enarson DA, Kennedy SM. State of the art. The impact of grain dust on respiratory health. $A m$ Rev Respir Dis 1992;145:476-87.

6 Cotton DJ, Graham BL, Li KY-R, Froh F, Barnett GD, Dosman JA. Effects of grain dust exposure and smoking on respiratory symptoms and lung function. $\mathcal{F}$ Occup Med on respiratory sym

7 Corey P, Hutcheon M, Broder I, Mintz S. Grain elevator workers show work related pulmonary function changes and dose-effect relationships with dust exposure. $\mathrm{Br} \mathcal{F}$ Ind Med 1982;39:330-7.

8 DoPico GA, Reddan W, Tsiatis A, Peters ME, Rankin J. Epidemiologic study of clinical and physiologic parameters in grain handlers of the northern United States. $A m \mathcal{F}$ Respir Dis 1984;130:759-65.

9 Dosman JA, Graham BL, Cotton DJ, Cockcroft DW, Li KY-R, Froh F, Bamett GD. Chronic bronchitis and decreased forced expiratory flow rates in lifetime nondecreased forced expiratory flow rates in lifetime nonsmoking

10 Sheridan D, Deutscher C, Tan L, Maybank J, Gerrard J, Hane $S$, et al. The relationship between exposure to cereal grain dust and pulmonary function in grain workers. In: JA Dosman, DJ Cotton, eds. Occupational pulmonary disease. Focus on grain dust and health. London: Academic Press, 1980, 229-38.

11 Smid T, Heederik D, Houba R, Quanjer PH. Dust and endotoxin related respiratory effects in the animal feed industry. Am Rev Respir Dis 1992;146:1474-9.

12 Huy $T$, de Schipper K, Chan-Yeung M, Kennedy SM.
Grain dust and lung function. Dose-response relationships. Am Rev Respir Dis 1991;47:1314-21.

13 Tielemans $E$ Heederik D, van Pelt W Changes in ventilatory function in grain processing and animal feed workers in relation to exposure to organic dust. Scand $\mathcal{f}$ Work in relation to exposure to organic
Environ Health 1990;20:435-43.

14 Dimich-Ward HD, Kennedy SM, Dittrick MA, DyBuncio $A$, Chan-Yeung $M$. An evaluation of the respiratory health of dock workers who load grain cargoes in British Columbia. Occup Environ Med 1995;52:273-8.

15 ter Kuile WM. Vergleichsmessungen mit verschiedenene Geraeten zur Bestimmung der Gesamtstaubkonzentration am Arbeitzplatz: Teil II. Staub Reinh Luft 1984;44:211-6. (In German.)

16 International Standards Office. Size definitions for particle sampling. Am Ind Hyg Assoc $\mathcal{F}$ 1981;42:A64-8.

17 Buchan, RM, Soderholm SC, Tillery, MI. Aerosol sampling efficiency of 37-mm filter cassettes. Am Ind Hyg Assoc ₹ 1986;47:825-31.

18 Medical Research Council Committee on the Aetiology of Chronic Bronchitis. Instructions for the use of the questionnaire on respiratory symptoms. Dawlish, England: Holman, 1966.

19 American Lung Association. Recommended respiratory diseases questionnaire for use with adults and children in epidemiological research. Am Rev Respir Dis 1978;118: $7-53$.

20 Chan-Yeung $M$, Wong $R$, MacLean L. Respiratory abnormalities among grain elevator workers. Chest 1979;75: 461-7.

21 Quanjer $\mathrm{PhH}$, ed. Standardized lung function testing. Report of the Working Party on Standardization of Lung Function Tests. Bull Europ Physiopath Respir 1983;19 (suppl 5):1-95.

22 Gardner RM. Snowbird workshop on standardization of spirometry (ATS statement). Am Rev Respir Dis 1979; 119:813-8.

23 Crapo RO, Morris AH, Gardner RM. Reference spirometric values using techniques and equipment that meet ATS recommendations. Am Rev Respir Dis 1981;123:659-64.

24 Cotton DJ, Graham BL, Li KY-R, Froh F, Barnett GD, Dosman JA. Effects of smoking and occupational expoDosman JA. Effects of smoking and occupational exposure on peripheral airway function in young

25 Broder I, Corey P, Davies G. Longitudinal study of grain elevator and control workers with demonstration of healthy worker effect. $f$ Occup Med 1985;27:873-80

26 James AL, Zimmerman MJ, Ee H, Ryan G, Musk AW Exposure to grain dust and changes in lung function. $\mathrm{Br} \dot{\mathrm{F}}$ Ind Med 1990;47:466-72.

27 Kennedy SM, Dimich-Ward H, Desjardins A, Kassam A, Vedal S, Chan-Yeung $M$. Respiratory health among retired grain elevator workers. Am $\mathcal{f}$ Respir Crit Care Med 1994;150:59-65.

28 Kennedy SM, Christiani DC, Eisen EA, Wegman DH, Greaves IA, Olenchock AS, et al. Cotton dust and endo-
toxin exposure response relationship in cotton textile toxin exposure response relationship in cotto
workers. Am Rev Respir Dis 1987;135:194-200.

29 Kenny LC. Pilot study of CEN protocols for the performance testing of workplace aerosol sampling instrument. 1995 (in press)

30 Zuskin E, Mataija M, Pokraja D. Respiratory function in animal food processing workers. Am F Ind Med 1989;16: 179-87. 